\title{
SERGANČIŲJŲ COVID-19 INFEKCIJA PLAUČIU巳 ARTERIJOS TROMBEMBOLIJA
}

\author{
Šarūnė Maksvytyte் ${ }^{1}$, Pranas Šerpytis ${ }^{1,2}$ \\ ${ }^{l}$ Vilniaus universiteto Medicinos fakultetas, ${ }^{2}$ Vilniaus universiteto ligonine Santaros klinikos
}

Raktažodžiai: COVID-19, plaučių arterijos trombembolija, paplitimas, patogeneze, antikoaguliacija, gliukokortikoidai.

\begin{abstract}
Santrauka
Koronavirusinè infekcija (COVID-19) - tai grèsminga visuomenés problema. Remiantis $2021 \mathrm{~m}$. balandžio mènesio duomenimis, ši infekcija nusineše daugiau nei 3 milijonus gyvybių. Dažniausia COVID-19 pacientų trombotinè komplikacija - plaučių arterijos trombembolija (PATE) siejama su dideliu sergamumu ir mirštamumu, reikalaujanti kuo ankstyvesnès diagnostikos ir gydymo. Tyrimo tikslas - atlikti mokslinių straipsnių, nagrinëjančių PATE paplitimą, patogenezę, diagnostiką ir gydymą COVID-19 infekcija sergančių pacientų populiacijoje, analizę. Literatūros apžvalgai naudoti 2020-2021 m. straipsniai. Remiantis atlikta apžvalga, pastebeta: PATE yra dažna pacientams, sergantiems sunkia COVID-19 sukelta pneumonija ar ūminiu respiracinio distreso sindromu (ŪRDS); šios būklès paplitimas yra didesnis, nei asmenų, sergančiu kitų virusinių infekcijų sukelta pneumonija ar URRDS; didesnis PATE paplitimas galimai susijęs su SARS-CoV-2 sukeliama imunotromboze; žymus D-dimerų koncentracijos padidèjimas gali būti stebimas ir PATE nekomplikuotos sunkios COVID-19 infekcijos atveju; šiuo metu trūksta duomenų apie optimalią profilaktinę antikoaguliaciją bei uždegimą slopinančių vaistų poveikị hemostazei COVID-19 pacientų populiacijoje.
\end{abstract}

\section{Ivadas}

Koronavirusinè infekcija (COVID-19) - tai grèsminga visuomenès problema, nusinešusi daugiau nei 3 milijonus gyvybių pasaulyje. Plaučių arterijos trombembolija yra dažniausia COVID-19 infekcija sergančių asmenų trombotinè komplikacija [1], susijusi su dideliu sergamumu ir mirštamumu, todèl reikalinga ankstyvos diagnostikos ir gydymo. Šioje literatūros apžvalgoje analizuojami moksliniai šaltiniai, kuriuose nagrinejjamas su COVID-19 infekcija susijusios PATE paplitimas, patogenezé, diagnostika ir gydymas.
Tyrimo tikslas - atlikti ne vèliau nei prieš dvejus metus publikuotų mokslinių straipsnių, nagrinèjančių plaučių arterijos trombembolijos paplitimą, patogenezę, diagnostiką ir gydymą COVID-19 infekcija sergančių pacientų populiacijoje, analizę.

\section{Tyrimo objektas ir metodika}

Duomenys buvo renkami PubMed duomenų bazèje. Analizei naudoti visateksčiai straipsniai, kuriu pavadinimas, santrauka ir raktažodžiai atitiko apžvalgos tikslą. Analizuotos anglų kalba skelbtos 2020-2021 m. publikacijos. Literatūros apžvalgai atrinkti 9 straipsniai.

\section{Rezultatai}

Pastaruoju metu atlikta nemažai tyrimų, kuriuose analizuojamas PATE paplitimas tarp SARS-CoV-2 infekcija sergančiu pacientų. G. Longchamp ir kt. sistemineje apžvalgoje ir metaanalizèje [2], kurioje dalyvavo 4009 57-69 m. COVID-19 pacientai, veninės trombembolijos (VTE) paplitimas tarp intensyviosios terapijos skyriaus (ITS) pacientų siekè net 21 proc., nors didžiojoje dalyje ị tyrimą ịtrauktų studijų taikyta farmakologinè trombozès profilaktika. Ne ITS ligonių minèta būklè sudare tik apie 2 proc. atvejų. Galimai toks paplitimo skirtumas sietinas su stipresniu uždegiminiu atsaku ir dažnesniu klasikinių rizikos veiksnių pasireiškimu ar ilgesne šių veiksnių poveikio trukme ITS pacientų populiacijose. Y. Suh ir kt. sisteminè apžvalga ir metaanalizè [3], i kurią įtraukti 3342 50-70 m. tiriamieji, parode, kad tarp COVID-19 sirgusiųjų 16,5 proc. turejo PATE ir 14,8 proc. - giliųjų venų trombozę (GVT). Didžiajai daliai pacientų trombų lokalizacija buvo stebima periferinèse plaučių arterijų dalyse. Tyrime didesnis PATE dažnis $(24,7 \%)$ stebetas tarp ITS gydytų COVID-19 ligonių. Nepaisant dažno PATE pasireiškimo, GVT paplitimas tarp COVID-19 pacientų atliktoje studijoje buvo mažesnis, nei bendrojoje PATE sergančiujų populiacijoje, todèl dažnesnis aptariamos būklès paplitimas galimai sietinas su specifinių SARS-CoV-2 infekcijai patofiziologinių mechanizmų, kitaip įvardijamų kaip COVID-19 sukelta imunotrombozè, poveikiu [4]. Tai galimai 
įrodo ir kai kurios COVID-19 pacientų su PATE autopsinès studijos, kuriose stebètas dažnas mikrotrombozių mažose ar vidutinio dydžio plaučių arterijos šakose pasireiškimas [5], bei kai kurie mažos apimties tyrimai, parodę didesnị PATE paplitimą tarp ITS skyriuose dèl COVID-19 sukeltos pneumonijos ar ūmaus respiracinio distreso sindromo gydytu pacientu, lyginant su pacientais, gydytais dèl gripo sukeltos pneumonijos ar ŪRDS $[1,2]$.

Virchovo triados veiksniai - endotelio pažeidimas, hiperkoaguliacija ir staze priskiriami tradiciniams trombogenezę sukeliantiems veiksniams. SARS-CoV-2 sukèlëjas jungiasi prie AKF-2 receptorių, randamų ne tik kvejpavimo takų epitelyje, bet ir kraujagyslių endotelyje, aktyvindamas renino-angiotenzino-aldosterono sistemą, trombocitų agregaciją ir skatindamas citokinų IL-2, IL-6 ir IL-10, TNF- $\alpha$ hiperprodukciją $[4,6]$. Viruso invazija ị ląsteles nulemia tiesioginį endotelio pažeidimą, pasireiškiantį von Willebrand faktoriaus bei makrofagų ir neutrofilų aktyvacija. Tai gali suaktyvinti neutrofilų ekstraceliulinių spąstų (angl. neutrophil extracellular traps, NET) formavimąsi ir sukelti COVID-19 infekcijai specifiškos imunotrombozès smulkesnèse plaučių arterijų šakose vystymąsi [3,7]. Yra duomenų, kad hiperkoaguliaciją COVID-19 infekcijos atveju skatina ir sukèlejo gebejjimas aktyvuoti piroptozę (uždegimo indukuotą programuotos ląstelès mirtį) bei su plaučių pažeidimu susijusi hipoksinè būklè [4]. Dèl uždegiminio proceso sergančių COVID-19 infekcija plaučiuose vystosi stazè, dar labiau didinanti trombozinių îvykių riziką. Didelę įtaką dažnesniam PATE pasireiškimui tarp ITS gydomų COVID-19 pacientų su ŪRDS turi ir kiti veiksniai, tokie kaip ilga imobilizacija, ilgalaikis raumenų relaksantų vartojimas, gretutinès ligos ar kateterių buvimas $[2,8]$.

COVID-19 infekcijos sukeliamiems simptomams būdinga sanklota su nespecifiniais PATE simptomais, sunkinanti aptariamos būklès diagnostiką. Ittariant veninę trombemboliją, atkreiptinas dèmesys ị tokius požymius, kaip staigiai didejanti hipoksemija, neproporcingai didelis deguonies poreikis (lyginant su rentgenologiniu pneumonijos vaizdu), staigus kraujospūdžio kritimas, naujai atsiradusi EKG registruojama tachikardija ar GVT būdingi požymiai [7]. Esant neryškiems PATE simptomams, naudotinos specifinès ( $\mathrm{Pa}$ $d u a$ ar Caprini) PATE predikcijos skalès [8]. Nors D-dimeru koncentracijos padidejjimas dažniausiai siejamas su didesne PATE rizika ir prastesne prognoze, tačiau šių žymenų koncentracijos kraujyje padidejimą gali nulemti ir sunki nekomplikuota PATE COVID-19 pneumonija [9], todèl PATE rizikos vertinimui svarbu atsižvelgti ir ị bendrą laboratorinių tyrimų ir klinikinių simptomų kontekstą. Pacientams įtarus GVT, turètų būti atliekama kompresinè venų ultrasonografija. KT angiografija (KTA) yra laikoma tiksliausiu, tačiau, kaip parodè kai kurios studijos, nepakankamai dažnai taikomu plaučių trombembolijos diagnostikos metodu [8]. Retas KTA taikymas susijęs su mažesniu šio metodo prieinamumu ir sunkia pacientų, kuriems itariama PATE, būkle (DPV, pronacija, IFN), sunkinančia šio diagnostikos metodo atlikimą.

Dabartiniu laikotarpiu visiems pacientams, hospitalizuotiems dèl COVID-19 infekcijos, rekomenduojamas profilaktinis antikoaguliantų skyrimas, tačiau kol kas nepakanka duomenu apie optimalią tromboprofilaktikos strategiją aptariamoje populiacijoje [7,9]. Nepaisant didejančio tyrimų, rodančių didesnę trombozinių komplikacijų riziką tarp COVID-19 pacientų, skaičiaus, duomenys apie dvigubai didesnès ar vidutinès mažos molekulinès masès heparinu dozių naudą vertinami nevienareikšmiškai [7]. Skiriant profilaktinę antikoaguliaciją, pirmenybė teiktina mažos molekulinès masès heparinams dèl parenterinio jų vartojimo ir galimybès skirti vienkartinę dienos dozę. Sergančiujų COVID-19 infekcijos su diagnozuota PATE gydymas remiasi standartinėmis gairèmis, nukreiptomis ị makrovaskulinès trombozès, tačiau ne ị viruso indukuotos koagulopatijos ir mikrovaskulinès trombozès gydymą [7]. Nors kai kurie tyrimai parodè, kad virusą slopinantis vaistas remdesiviras pagreitina hospitalizuotujų dèl COVID-19 sveikimo trukmę [10], kol kas neaišku, ar šis vaistas mažina trombotinių komplikacijų riziką. Gliukokortikoidų ir IL-6 inhibitoriaus tocilizumabo nauda COVID-19 sergantiems pacientams ịvairiose studijose vertinama skirtingai [7]; vis dar trūksta duomenų, kuriuose nagrinèjamas šių vaistų poveikis COVID-19 infekcija sergančiu pacientų hemostazei. $2021 \mathrm{~m}$. A. Sarfraz ir kt. sisteminè apžvalga ir metaanalizė [6] parodè, kad gliukokortikoidų skyrimas susijęs su didesne veninès trombembolijos rizika, tačiau atkreiptinas dèmesys, kad dèl ị studiją ịtrauktų tyrimų heterogeniškumo ir skirtingų kortikosteroidų režimų nėra pakankamo pagrindo daryti vienareikšmiškas išvadas.

\section{Išvados}

1. PATE yra dažna tarp pacientų, sergančių sunkia COVID-19 sukelta pneumonija ar ÜRDS.

2. PATE paplitimas ITS tarp COVID-19 pacientu didesnis, nei tarp sergančiujų ITS gydomų dèl kitų virusinių infekcijų.

3. Dažnesnis PATE pasireiškimas COVID-19 sergančiųjų populiacijoje siejamas su SARS-CoV-2 sukeliama in situ imunotromboze.

4. Žymus D-dimerų koncentracijos padidèjimas gali būti susijęs ir su PATE nekomplikuota COVID-19 infekcija.

5. Šiuo metu trūksta duomenų apie optimalią COVID-19 pacientų profilaktinę antikoaguliaciją bei specifinio antivirusinio gydymo poveiki hemostazei COVID-19 pacientų populiacijoje. 


\section{Literatūra}

1. McFadyen JD, Stevens H, Peter K. The emerging threat of (micro)thrombosis in COVID-19 and its therapeutic implications. Circ Res 2020;127(4):571-87. https://doi.org/10.1161/CIRCRESAHA.120.317447

2. Longchamp G, Manzocchi-Besson S, Longchamp A, Righini M, Robert-Ebadi H, Blondon M. Proximal deep vein thrombosis and pulmonary embolism in COVID-19 patients: a systematic review and meta-analysis. Thromb J. 2021;19(1):15. https://doi.org/10.1186/s12959-021-00266-X

3. Suh YJ, Hong H, Ohana M, Bompard F, Revel M-P, Valle C, et al. Pulmonary embolism and deep vein thrombosis in COVID-19: a systematic review and meta-analysis. Radiology 2020;298(2):E70-80.

https://doi.org/10.1148/radiol.2020203557

4. Manolis AS, Manolis TA, Manolis AA, Papatheou D, Melita H. COVID-19 infection: viral macro- and micro-vascular coagulopathy and thromboembolism/prophylactic and therapeutic management. J Cardiovasc Pharmacol Ther 2021;26(1):12-24. https://doi.org/10.1177/1074248420958973

5. Lax SF, Skok K, Zechner P, Kessler HH, Kaufmann N, Koelblinger $\mathrm{C}$, et al. Pulmonary arterial thrombosis in covid-19 with fatal outcome: results from a prospective, single-center, clinicopathologic case series. Ann Intern Med 2020. https://doi.org/10.2139/ssrn.3586685

6. Sarfraz A, Sarfraz Z, Razzack AA, Patel G, Sarfraz M. Venous thromboembolism, corticosteroids and COVID-19: a systematic review and meta-analysis. Clin Appl Thromb 2021;27:1076029621993573. https://doi.org/10.1177/1076029621993573

7. Kaptein FHJ, Stals MAM, Huisman MV, Klok FA. Prophylaxis and treatment of COVID-19 related venous thromboembolism. Postgrad Med 2021;1-9. https://doi.org/10.1080/00325481.2021.1891788

8. Roncon L, Zuin M, Barco S, Valerio L, Zuliani G, Zonzin P, et al. Incidence of acute pulmonary embolism in COVID-19 patients: systematic review and meta-analysis. Eur J Intern Med 2020;82:29-37.

https://doi.org/10.1016/j.ejim.2020.09.006
9. BTS guidance on venous thromboembolic disease in patients with COVID-19. British Thoracic Society, pdf 2021.

10. Beigel JH, Tomashek KM, Dodd LE, Mehta AK, Zingman BS, Kalil AC, et al. Remdesivir for the treatment of Covid-19 - final report. N Engl J Med 2020;383(19):1813-1826.

https://doi.org/10.1056/NEJMoa2007764

\section{PULMONARY EMBOLISM AMONG PATIENTS PRESENTING WITH COVID-19 INFECTION}

\section{Š. Maksvytytè, P. Šerpytis}

Keywords: COVID-19, pulmonary embolism, prevalence, pathogenesis, anticoagulation, glucocorticoids.

Summary

Coronavirus disease (also known as COVID-19) is a global public threat, according to the newest data from April 2021, resulting in more than 3 million deaths worldwide. Pulmonary embolism (PE), which is thought to be the most prevalent thrombotic complication among COVID-19 patients, is associated with high morbidity and mortality rates thus requiring early diagnosis and treatment. The aim of this literature review is to analyse the literature about prevalence, pathogenesis, diagnostics, and treatment of COVID-19 related PE. The articles from 2020 to 2021 were used for the literature review. Based on the review, it was observed that $\mathrm{PE}$ is prevalent among COVID-19 patients with severe pneumonia and acute respiratory distress syndrome (ARDS) and more prevalent than among patients presenting with pneumonia or ARDS associated with other viral infections; higher frequency of $\mathrm{PE}$ is probably related to SARS-CoV-2 ability to induce immunothrombosis; high D-dimer concentrations can also be found in non-PE COVID-19 cases; there is not enough data regarding thromboprophylaxis and impact of anti-inflammatory drugs on hemostasis in COVID-19 population.

Correspondence to: sarune25@gmail.com

Gauta 2021-04-28 